\title{
Judging National Security post-9/11: An Empirical Investigation
}

\section{Citation}

Cass R. Sunstein, Judging National Security post-9/11: An Empirical Investigation (John M. Olin Program in Law \& Economics Working Paper No. 441, 2008).

\section{Published Version}

http://chicagounbound.uchicago.edu/law_and_economics/291/

\section{Permanent link}

http://nrs.harvard.edu/urn-3:HUL.InstRepos:12795533

\section{Terms of Use}

This article was downloaded from Harvard University's DASH repository, and is made available under the terms and conditions applicable to Open Access Policy Articles, as set forth at http:// nrs.harvard.edu/urn-3:HUL.InstRepos:dash.current.terms-of-use\#OAP

\section{Share Your Story}

The Harvard community has made this article openly available.

Please share how this access benefits you. Submit a story.

Accessibility 


\section{University of Chicago Law School Chicago Unbound}

Coase-Sandor Working Paper Series in Law and

Economics

Coase-Sandor Institute for Law and Economics

2008

\section{Judging National Security post-9/11: An Empirical Investigation}

Cass R. Sunstein

Follow this and additional works at: http://chicagounbound.uchicago.edu/law_and_economics Part of the Law Commons

\section{Recommended Citation}

Cass R. Sunstein, "Judging National Security post-9/11: An Empirical Investigation" (John M. Olin Program in Law and Economics Working Paper No. 441, 2008).

This Working Paper is brought to you for free and open access by the Coase-Sandor Institute for Law and Economics at Chicago Unbound. It has been accepted for inclusion in Coase-Sandor Working Paper Series in Law and Economics by an authorized administrator of Chicago Unbound. For more information, please contact unbound@law.uchicago.edu. 


\title{
CHICAGO
}

John M. Olin LAW \& ECONOMics WORKING PAPER No. 441

(2D SERIES)

Public LaW and Legal Theory Working Paper No. 245

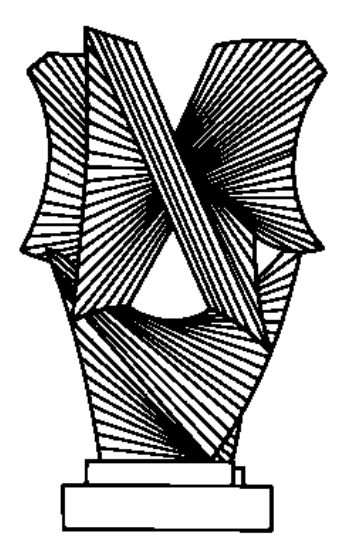

\section{JUDGING NATIONAL SECURITY POST-9/11: AN EMPIRICAL INVESTIGATION}

\author{
Cass R. Sunstein
}

\section{THE LAW SCHOOL THE UNIVERSITY OF CHICAGO}

November 2008

This paper can be downloaded without charge at the John M. Olin Program in Law and Economics Working Paper Series: http://www.law.uchicago.edu/Lawecon/index.html and at the

Public Law and Legal Theory Working Paper Series:

http://www.law.uchicago.edu/academics/publiclaw/index.html

and The Social Science Research Network Electronic Paper Collection. 


\title{
Judging National Security Post-9/11: An Empirical Investigation
}

\author{
Cass R. Sunstein
}

\begin{abstract}
Many people believe that when national security is threatened, federal courts should defer to the government. Many other people believe that in times of crisis, citizens are vulnerable to a kind of "panic" that leads to unjustified intrusions on liberty. But to date, there is little information about what federal courts have actually done in this domain, especially in the period after the attacks of September 11, 2001. On the basis of a comprehensive study of relevant courts of appeals decisions in the aftermath of those attacks, this essay offers four findings. First, the invalidation rate is about 15 percent low, but not so low as to suggest that federal courts have applied a broad rule of deference to government action. Second, the division between Republican and Democratic appointees is comparable to what is found in other areas of the law; contrary to reasonable expectations, there is no significant "compression" of ideological divisions in this domain. Third, and perhaps most strikingly, no panel effects are apparent here. Unlike in the vast majority of other areas, Republican and Democratic appointees do not appear to vote differently if they are sitting with Republican or Democratic appointees. Finally, judicial behavior cannot be shown to have changed over time. The invalidation rate is not higher in recent years than it was in the years immediately following the 9/11 attacks. Explanations are ventured for these various findings, with particular reference to the absence of discernible panel effects.
\end{abstract}

\section{Introduction}

In the aftermath of the attacks of September 11, 2001, Congress and the executive branch have embarked on a number of new initiatives, raising a series of fresh legal questions. ${ }^{1}$ Many of those questions involve the relationship between national security and some kind of individual right. Does the president have the authority to detain people without trial ${ }^{2}$ Do existing provisions of law allow the use of military commissions? ${ }^{3}$ Can certain information be withheld from the public? ${ }^{4}$ When, exactly, does the government

\footnotetext{
* Felix Frankfurter Professor of Law, Harvard Law School. I am grateful to the Program on Risk Regulation for valuable support; to Elisabeth Theodore, Emily Ullman, Beth Bell, and Jason Yen for indispensable research assistance; and to Cassandra Wolos for the statistical analysis, which saved me from many errors. Martha Nussbaum and Geoffrey Stone provided valuable comments on a previous draft. Special thanks to Adrian Vermeule for discussions that inspired this project; those discussions produced the hypotheses that are tested here.

${ }^{1}$ The literature is voluminous. For one account, see David Cole and Jules Lobel, Less Safe, Less Free: Why America is Losing the War on Terror (2007).

${ }^{2}$ See Hamdi v Rumsfeld, 542 U.S. 407 (2004).

${ }^{3}$ See Hamdan v Rumsfeld, 548 U.S. 557 (2006).

${ }^{4}$ See ACLU v. Dept. of Def., No. 06-3140-cv, 2008 WL 4287823 (2d. Cir. Sept. 22, 2008).
} 
need a search warrant to obtain access to previously private information ${ }^{5}$ May the executive engage in wiretapping? ${ }^{6}$

It is easy to find two sets of recommendations for how courts should approach such questions. On a widely held view, judicial deference is the appropriate presumption or even rule. ${ }^{7}$ Courts lack information about the potentially serious consequences of their judgments, and the elected branches are the best position to balance the competing considerations. If courts should generally be reluctant to invalidate the decisions of the executive and legislative branches, ${ }^{8}$ then their reluctance should be increased when national security is at stake.

On a competing view, also widely held, the argument for a strong judicial role is not at all weakened when a national security threat leads the elected branches to test the legal boundaries. ${ }^{9}$ In "perilous times," 10 it might be thought, those branches are especially prone to a serious form of lawlessness, and it becomes all the more important for courts to insist on compliance with the rule of law. On this view, the system of checks and balances, including an independent judiciary, is no less dispensable when the stakes are high and damaging intrusions on liberty are likely. ${ }^{11}$ Defenders of this position contend that history is on their side: Intrusions on civil liberties, popular at the time but indefensible in retrospect, have occurred at many periods in American history. ${ }^{12}$

While the competing normative positions have been defended in great detail, we know much less about what courts actually do. The literature on that question is sparse. ${ }^{13}$ In the post-9/11 era, it is essentially nonexistent. In this essay, I describe the results of an effort to compile and analyze all relevant courts of appeals decisions between 9/11 and the present. The principal findings are as follows:

1. The overall rate of invalidation is low. The government loses only $15 \%$ of the litigated cases - a lower figure than in almost all other domains of federal law.

2. There is a significant difference between the voting patterns of Republican appointees and those of Democratic appointees. The Republican invalidation rate is $12 \%$; the Democratic invalidation rate is $23 \%$.

3. In this domain, the standard panel effects are not found. The voting patterns of Republican appointees do not differ if they are sitting with zero, one, or two Republican appointees. The voting patterns of Democratic appointees are not affected by whether they are sitting with zero, one, or two Democratic appointees.

\footnotetext{
${ }^{5}$ See, e.g., US v. bin Laden, 126 F. Supp. 2d 264 (SDNY 2000).

${ }^{6}$ See ACLU v. NSA, 493 F.3d 644 (6th Cir. 2006).

7 See Richard A. Posner, Not A Suicide Pact (2007); Eric Posner and Adrian Vermeule, Terror in the Balance (2007).

${ }^{8}$ See Adrian Vermeule, Judging Under Uncertainty (2006).

${ }^{9}$ See David Cole and Lobel, supra note.

${ }^{10}$ See Geoffrey Stone, Perilous Times (2004).

${ }^{11}$ See William Rehnquist, All The Laws But One (1997), for a qualified endorsement of this view.

12 See id.

13 The best discussion is Lee Epstein et al., The Supreme Court During Crisis, 80 NYU L Rev 1 (2005).
} 
This is a highly unusual finding; in the vast majority of domains of federal law, judicial votes are greatly affected by panel composition. ${ }^{14}$

4. Invalidation rates have not changed over time. Contrary to what might well be expected, the invalidation rate was the same in the first three years after the attacks of $9 / 11$ as in the following four years.

My goal here is to elaborate these results and to offer some comments and explanations. In the process, I aim not only to explore the national security cases post9/11, but also to provide some more general remarks on the analysis of judicial voting patterns, and about what can and cannot be learned from quantitative studies of this sort. Part II offers a discussion of background and method; it also outlines the central findings. Part III attempts to explain them, with particular emphasis on ideological voting and on the largest puzzle, which is the absence of the standard panel effects. Part III explores why judicial votes, in ideologically contested cases, are typically affected by the votes of other judges on the panel. In the process, it offers an account of why the typical pattern is not observed in national security cases, and of when and why we should expect to see judges (and perhaps others) strongly affected by the views of their colleagues.

\section{Background, Method, Results}

\section{A. Ideological Differences and Panel Effects}

To understand the current study, it is important to have a general sense of other studies of judicial behavior, which have revealed three pervasive phenomena. The first is ideological voting. In numerous areas, Republican and Democratic appointees show significant differences in liberal voting rates. ${ }^{15}$ This finding is based on conventional measures of ideological differences, by counting, as a "liberal vote," a judgment in favor of (for example) affirmative action programs, campaign finance regulation, plaintiffs in sex discrimination cases, the right to choose abortion, or labor unions in cases involving the National Labor Relations Act. The difference between Republican and Democratic appointees varies by case category, but in many areas, it is significant; in a large data set, the overall difference is 12 percent. $^{16}$

Of course it would be a mistake to conclude, from this difference, that judicial voting can be reduced to ideological predispositions. Even in the most ideologically contested domains, most decisions are unanimous, and judges typically agree across party

\footnotetext{
${ }^{14}$ See, e.g., Frank Cross, Decision Making in the U.S. Courts of Appeals (2006); James Brudney et al., Judicial Hostility Toward Labor Unions? Applying the Social Background Model to a Celebrated Concern, 60 Ohio LJ 1675 (1999); Richard Revesz, Environmental Regulation, Ideology, and the DC Circuit, 83 Virginia Law Review 1717 (1983); William M. Landes and Richard A. Posner, Rational Judicial Behavior: A Statistical Study, Journal of Legal Analysis (forthcoming 2009); Sunstein et al., supra note.

${ }^{15}$ Landes and Posner, supra note; Sunstein et al., supra, at 20-21; Cross, supra note.

${ }^{16}$ Id.; Landes and Posner, supra note.
} 
lines. Nonetheless, Republican and Democratic appointees show significant differences in liberal voting rates. Those differences mean that the outcome of many disputes is determined by the random assignment of judges to panels. ${ }^{17}$

The second phenomenon is ideological dampening. When they are in the minority on three-judge panels, both Republican and Democratic appointees show significantly more moderate voting patterns than when they are in the majority. ${ }^{18}$ Apparently both sets of appointees are willing to offer collegial concurrences -- that is, they are willing to concur in cases even if they would reach a different result if they were in the majority. A simple way to demonstrate ideological dampening is to compare the voting patterns of Republican appointees on Republican-Democratic-Democratic (RDD) panels with those of Democratic appointees on Democratic-Republican-Republican (DRR) panels. In many areas of the law, those patterns are essentially identical. ${ }^{19}$ Even when there is a significant overall difference between Republican and Democratic appointees, that difference is in that sense essentially wiped out because of panel effects.

For example, Democratic appointees vote for sex discrimination plaintiffs 42 percent of the time on RRD panels, while Republican appointees vote for such plaintiffs 44 percent of the time on RDD panels. ${ }^{20}$ Note that even on such panels, Democratic appointees show more liberal voting rates than do Republican appointees. On RRD panels, for example, Republican appointees vote for sex discrimination plaintiffs 37 percent of the time, well below the 42 percent rate for Democratic appointees on such panels. ${ }^{21}$ But ideological dampening is nonetheless significant, in the sense that the ideological tendencies of both sets of appointees are muted.

The third phenomenon is ideological amplification. When sitting on panels consisting solely of appointees from the same political party (DDD or RRR panels), federal judges show significantly more ideological voting patterns than when sitting on mixed panels. ${ }^{22}$ A simple way to show this difference is to compare the overall difference between Republican and Democratic appointees with the difference on unified panels, with the latter counting as the "polarized difference."23 The polarized difference is often double or even triple the overall difference. For example, Republican appointees show a liberal voting rate of 37 percent in sex discrimination cases, well below the Democratic rate, which is 52 percent. ${ }^{24}$ But on RRR panels, Republican appointees show a liberal voting rate of 30 percent, and on DDD panels, Democratic appointees show a liberal voting rate of 60 . The polarized difference of 30 percent is of course double the overall

\footnotetext{
${ }^{17}$ Id.

${ }^{18}$ Sunstein et al., supra note, at 26-27.

${ }^{19}$ Id.

${ }^{20} \mathrm{Id}$. at 26.

${ }^{21}$ Id.

${ }^{22}$ Id.

${ }^{23}$ Id. at 20-21.

${ }^{24} \mathrm{Id}$. at 20 .
} 
difference of 15 percent. Differences of this magnitude are typical; they are the rule, not the exception. ${ }^{25}$

In numerous areas of federal law, ideological voting, ideological dampening, and ideological amplification are the basic findings. ${ }^{26}$ It follows that the political affiliation of the appointing president is a relatively good predictor of judicial voting in ideologically contested cases - but that the political affiliation of the president who appointed the other two judges on the panel is at least a good predictor of judicial voting in such cases! These findings suggest that the standard figure, for judicial voting behavior, looks roughly like this:

\section{Figure 1}

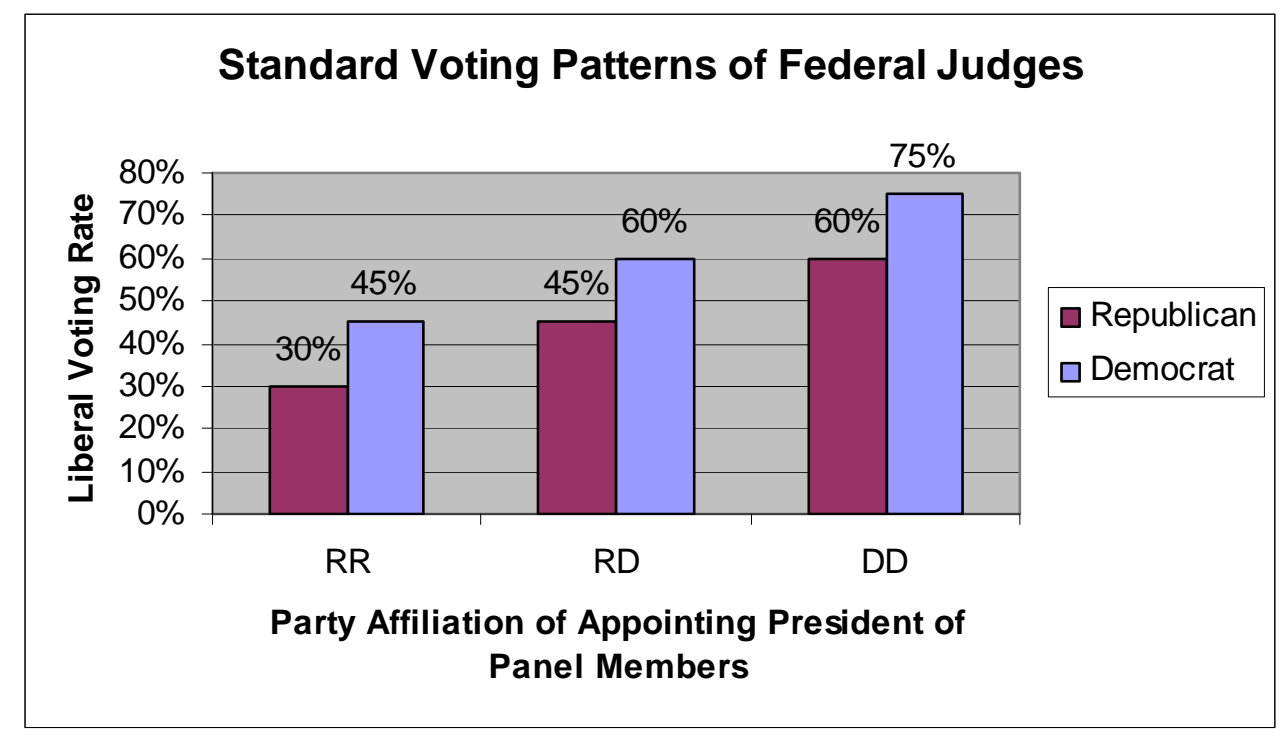

In a few areas, however, these patterns are not observed. First, ideological voting cannot be found in certain domains in which it might be expected; for example, there is no significant difference between Democratic and Republican appointees in criminal appeals and in cases involving the takings clause, congressional power under the Commerce Clause, punitive damages, and standing to sue. ${ }^{27}$ It is possible that existing doctrine imposes significant discipline on judges in such cases, in such a way as to ensure that ideological predispositions do not matter to judicial votes. It is also possible that federal judges do not much disagree, across party lines, in such cases, and hence ideological voting is not observed.

Second, panel effects cannot be found in cases involving abortion and capital punishment. ${ }^{28}$ In those domains, ideological voting is unmistakable, in the sense that the

${ }^{25}$ Id. at $26-27$.

${ }^{26}$ See note supra.

${ }^{27}$ Sunstein et al., supra note, at 49.

${ }^{28}$ Id. 
disparity between Democratic and Republican appointees is substantial. But the votes of federal judges are unaffected by panel composition. Apparently judicial convictions are especially strong in this context, and hence neither ideological dampening nor ideological amplification is observed. How can the absence of those standard findings be explained? I shall turn to that question in Part III.

Interestingly, and contrary to a reasonable prediction, the extent of the overall difference between Republican and Democratic appointees does not predict the existence of panel effects. In abortion cases, the overall difference in liberal voting is 16 percent. In capital punishment cases, it is 24 percent. The difference in liberal voting rates is even higher in the domain of affirmative action (28 percent) than in either of these areas, and it is also high in cases involving the National Environmental Policy Act (24 percent), abrogation of state immunity under the Eleventh Amendment (21 percent), sex discrimination (17 percent), and disability discrimination (16 percent). ${ }^{29}$ But in those four areas, panel effects are substantial, as both ideological dampening and amplification are found. ${ }^{30}$ What matters, then, is not the extent of the difference between the two sets of appointees, but the tenacity with which they maintain their convictions, and the former does not predict the latter.

With this background, let us turn to the national security cases.

\section{B. Method}

The data set consists of 111 courts of appeals decisions handed down between September 11, 2001 and September 10, 2008. The data set was generated by searching databases for a series of national security-related keywords ${ }^{31}$ and then manually eliminating cases that turned out to be irrelevant. Cases were excluded if they did not seriously engage national security issues, if they involved review of immigration or asylum decisions, or if the federal government was not a party. Because a central goal of the project is to analyze panel effects, en banc decisions were also excluded. Not surprisingly, the cases that make up the data set involve highly disparate subjects; common themes included challenges to detention, to surveillance, or to government efforts to conceal information.

Judicial votes were categorized in terms of whether they favored the government. In the overwhelming majority of cases, this measure was simple to apply, but in some

\footnotetext{
${ }^{29}$ Id. at $20-21$.

${ }^{30}$ Id. at $26-27$.

${ }^{31}$ The initial search string in Westlaw's "cta" database was: (FISA "EXTRAORDINARY RENDITION" ATLEAST3(TORTURE) GUANTANAMO "PATRIOT ACT" SY,DI("SEPTEMBER 11" "9/11" "NATIONAL SECURITY" TERRORISM TERRORIST TORTURE "WAR ON TERROR") ((("NATIONAL SECURITY" \& TERROR!) ATLEAST3(TERROR!) ATLEAST3("NATIONAL SECURITY")) \& (FOIA WIRETAP DETAIN! DETENTION SURVEILLANCE "9/11" "SEPTEMBER 11")) \& da(aft 9/11/2001) \& da(bef 9/14/2008) \% ("IMMIGRATION JUDGE" "BOARD OF IMMIGRATION APPEALS"))
} 
cases the categorization was not straightforward, because several issues were involved, and the government won on some of them but lost on others. In such cases, the government was said to have "won" if the government received most of what it wanted and lost on a minor or peripheral issue. In these few cases, a discretionary judgment had to be made on that question. United States $v$. Moussaoui, ${ }^{32}$ for example, the coding decision was not straightforward. The court of appeals ruled that it could order the government to produce enemy combatant witnesses for depositions, that a particular witness would be material to the Moussaoui defense, and that the particular deposition substitute proposed by the government was inadequate. But the court nevertheless affirmed the government's central proposal, which was to offer a written substitute instead of producing the witness. This result was counted as a victory for the government. Discretionary judgments of this kind were necessary only in a very small subset of the cases.

By our count, the panel majority found in favor of the government in a total of 94 cases out of a total of 111 . As is standard, judges were classified as Democratic or Republican appointees based on the party affiliation of the president who nominated them. $^{33}$

\section{Results}

Here are the basic results:

Figure 2

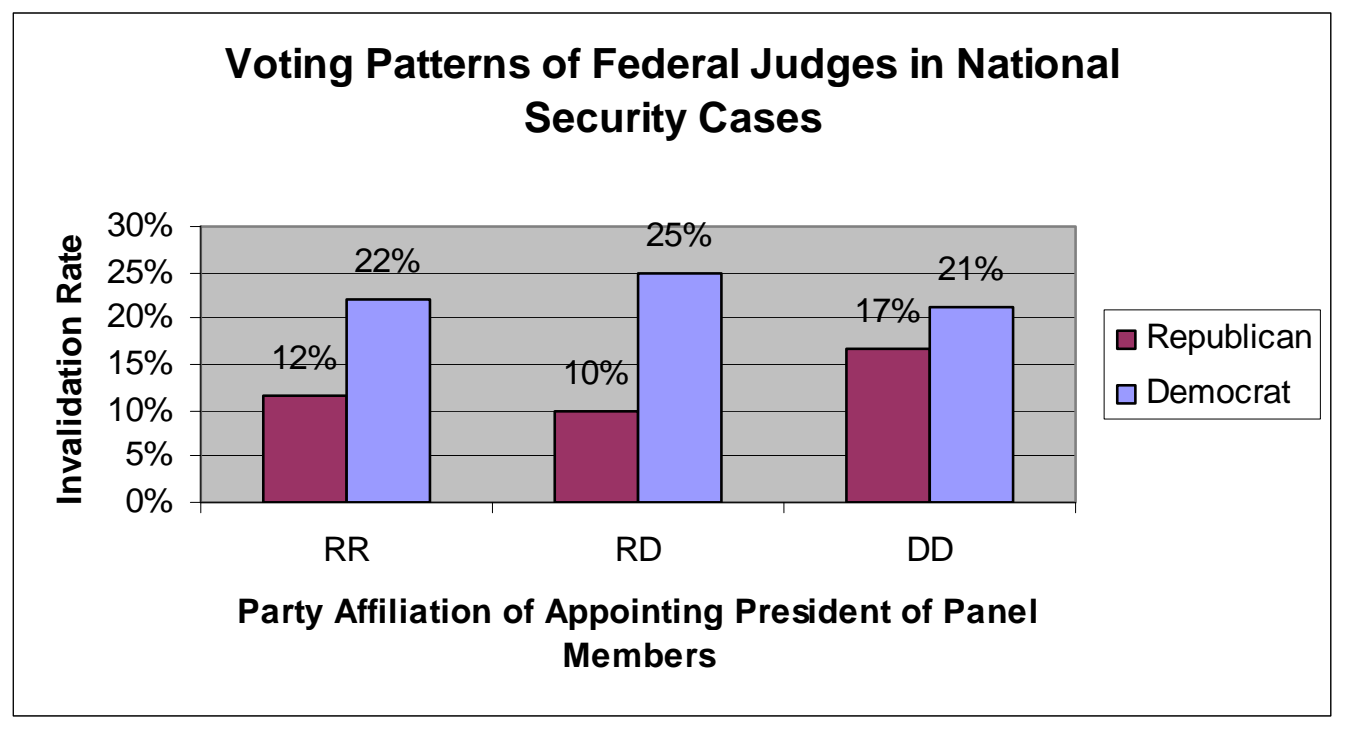

32365 F.2d 292 (4th Cir. 2004).

${ }^{33}$ One judge had been nominated to a district court position by a Democrat and to his circuit court position by a Republican. Because the judge is himself a registered Democrat, he was assigned that affiliation for purposes of the analysis. 


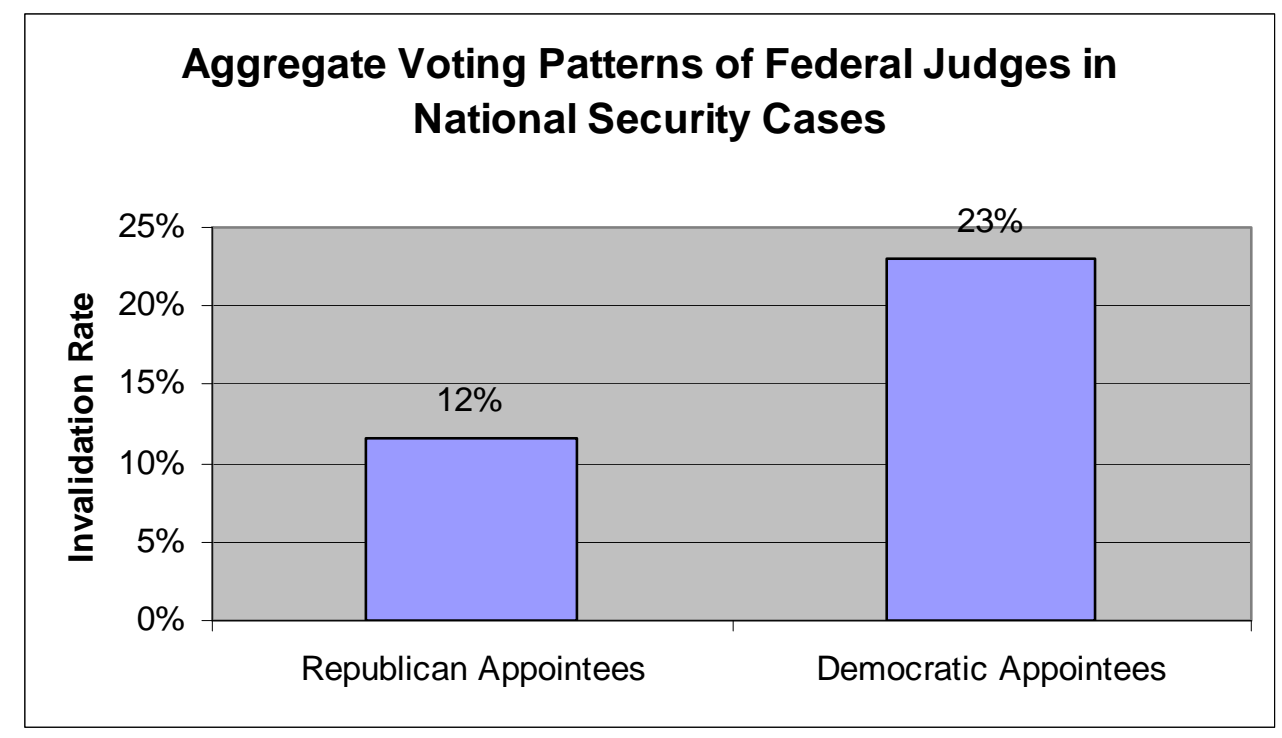

The most noteworthy findings are simple to describe.

1. The overall invalidation rate is low - about 15 percent. In terms of expected outcomes, very few areas of the law have been found to be so lopsided. For example, criminals win their appeals about one-third of the time, ${ }^{34}$ punitive damage awards are invalidated over one-fifth of the time, ${ }^{35}$ property owners win takings claims about 20 percent of the time, ${ }^{36}$ and disability plaintiffs win discrimination suits about one-third of the time. ${ }^{37}$ Of areas that have been studied, the only one with a more lopsided rate involves challenges to congressional power under the Commerce Clause, in which the victory rate is about 5 percent. $^{38}$

2. It might well be expected that the difference between Republican and Democratic appointees would be compressed in this domain. The area of national security might eliminate party differences; no judge would lightly rule that the government lacks authority to do what it deems necessary to protect the country. Surprisingly, however, there is no discernible compression. In a large data set, involving many domains, the average difference between the two sets of appointees was 12 percent; in ideologically contested cases as a whole, it was 15 percent. ${ }^{39}$ The difference here is 11 percent, which is statistically significant and very much in line with the overall findings. It is comparable to the differences in cases involving campaign finance regulation (14

\footnotetext{
${ }^{34}$ Sunstein et al., supra note, at 49.

${ }^{35}$ Id.

${ }^{36}$ Id.

${ }^{37}$ Id. at 26.

38 Id. at 39.

${ }^{39}$ See id. at 21.
} 
percent), obscenity (9 percent), racial discrimination under Title VII (9 percent), and desegregation (9 percent). ${ }^{40}$

To be sure, the 11 percent difference is lower than what is observed at the highest end of the range of domains studied to date; in cases decided under the National Environmental Policy Act, there is a 24 percent difference, and in affirmative action cases, the difference is 24 percent. $^{41}$ But it cannot be said that Democratic and Republican appointees behave essentially the same in national security cases. Nor can it be said that the level of difference, in this domain, is significantly lower than what it is in most domains in which ideological voting is observed.

3. It might also be expected that national security cases would follow the standard pattern shown in Figure 1, with rising liberal voting rates as the number of Democratic appointees increases, reflective of ideological dampening and ideological amplification. Because the sample size is relatively small, any conclusions on this point must remain somewhat tentative; but no such pattern is observed. The voting patterns of Democratic appointees cannot be shown to be associated with panel composition. Such appointees vote to invalidate government action about one-fifth of the time regardless of whether they are sitting with zero, one, or two Democratic appointees. In a striking contrast to other areas of the law, Republican appointees show the same voting patterns on RRD and RRR panels. To be sure, such appointees seem to show a modest shift in the liberal direction on RDD panels, but the difference is not statistically significant. The more general point is that none of the panel effects even approaches statistical significance.

4. We might anticipate that in the immediate aftermath of the $9 / 11$ attacks, say between 2002 and 2004, judges would show a high rate of deference to the executive branch, and that validation rates would decrease from 2006 to 2008. In the aftermath of the attacks, the threat would be immediate, and courts might well be reluctant to invalidate government action that was initiated in order to reduce the relevant risks. As the immediacy of the attacks receded, perhaps judges would come to think that the danger had been overstated; perhaps they could be more willing to invalidate government action.

No such pattern is observed. The rate of validation is essentially constant over the two time periods. The three plots in Figure 3 show the trend in invalidation rates; for clarity of exposition, they divide the relevant time period in different ways. The first plot divides the cases into three periods and calculates the rates within each period; the second

gives annual invalidation rates; the third divides the cases into eleven time periods and calculates the rate within each period.

\footnotetext{
${ }^{40}$ Id. at $20-21$.

${ }^{41}$ Id. at 20.
} 
Figure 3

Invalidation Rate over Time

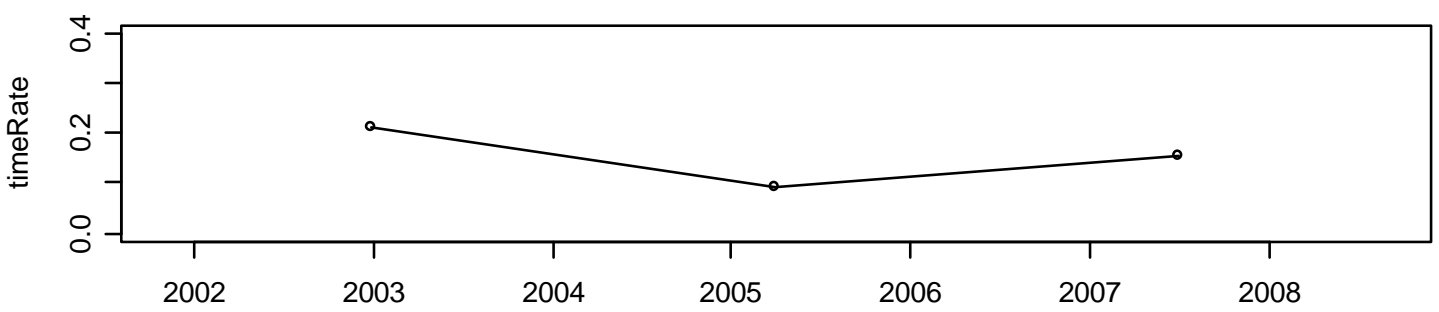

Invalidation Rate over Time

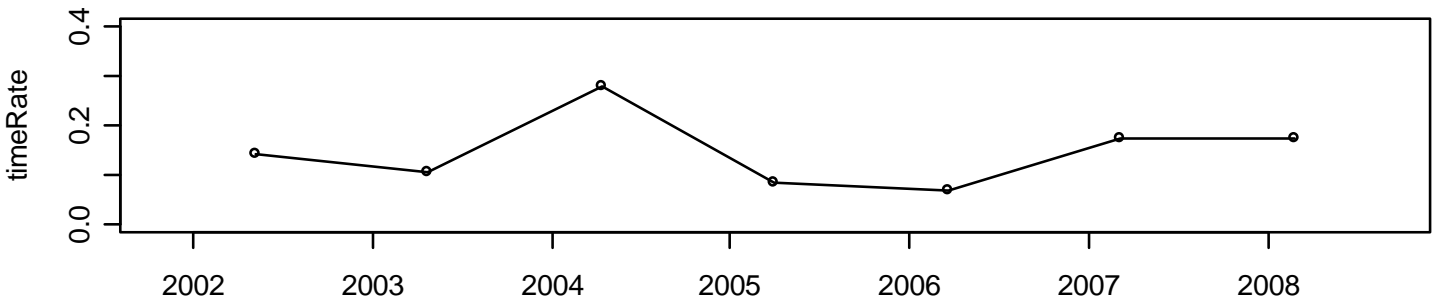

Invalidation Rate over Time

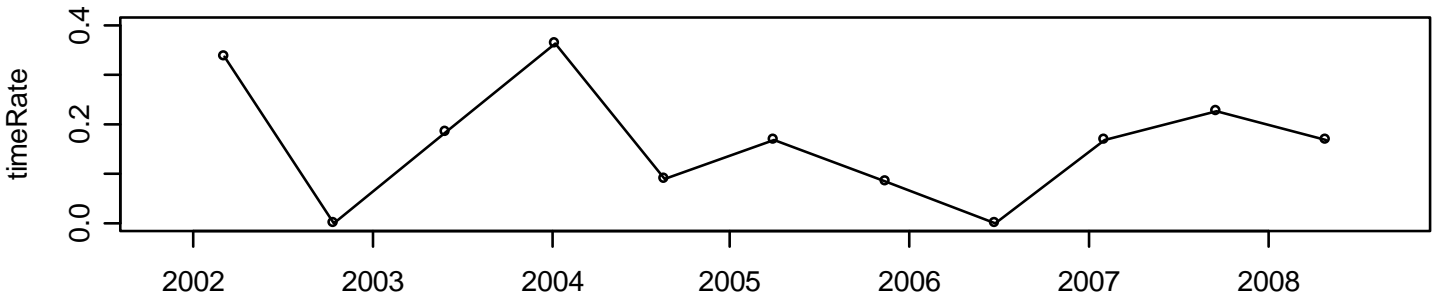

Not surprisingly, the shorter time intervals show more variable invalidation rates, but the differences are not significant. The general point is that there is no measurable increase in invalidation rates over the time period studied; if anything, the invalidation rate actually decreases, but the trend is not statistically significant.

\section{Explanations and Observations}

What lessons can be drawn from these findings? How do they compare with other domains of the law? What might be said about the approach of federal courts of appeals, after $9 / 11$, to actions of government that are challenged in court? 


\section{A. Invalidation Rates}

1. Two conclusions. The invalidation rate seems to suggest two conclusions. First, federal judges have been showing a high rate of deference to the executive branch. ${ }^{42}$ Second, the rate of deference is not nearly as high as it might be, or as it might be expected to be. Judges have not adopted anything like an irrebuttable presumption in government's favor. In other words, the existing voting patterns seem to suggest that federal courts have repudiated both of the polar positions in the academic debate.

2. Selection effects. These conclusions are reasonable and probably even correct, but we need to be careful with specific inferences. To evaluate the findings, it is necessary to ask two questions. What exactly is government doing in the relevant cases? And when are litigants willing to challenge government action? Without answers to these questions, any evaluations must be tentative.

We could easily imagine a world in which total invalidation rates were significantly higher - say, 25 percent. But perhaps the higher invalidation rates, in that world, would be a product not of a more aggressive judiciary, but of greater litigant selectivity in deciding when to challenge government action. Such selectivity might stem from multiple sources. Perhaps social pressures are leading people to challenge government action, in this domain, only when it is clearly unlawful; or perhaps litigants are highly risk-averse, fearing that adverse rulings could entrench bad law. In short, a relatively high invalidation rate might reflect the selection of cases for litigation, and might not tell us that federal courts are not being deferential.

Alternatively, we could imagine a world in which total invalidation rates were significantly lower than they are now -- say, five percent. But perhaps the lower rates, in such a world, would be a product of greater litigant willingness to challenge government action -- and also of greater caution, on the part of government, about testing the legal frontiers. Perhaps ideological litigants, in such a world, would challenge government action not only when they had a significant chance of success, but also for political or expressive reasons; perhaps they would not greatly fear validation. Perhaps government, in such a world, would stay well within the legal boundaries, fearing the consequences of invalidation in terms of frustration of its objectives, adverse public reactions, or both. If so, a low invalidation rate would not suggest a high level of judicial deference.

Which world is closer to ours? Without knowing, we cannot draw clear inferences about judicial aggressiveness. But it is nonetheless true that the 15 percent invalidation rate suggests both that courts are not adopting a broad rule of deference and that they are usually giving the government the benefit of the doubt.

3. No changes over time. As I have suggested, it might be expected that invalidation rates would increase over time. In the period immediately following the 9/11

\footnotetext{
${ }^{42}$ For an interesting hypothesis about high deference rates from the lower courts, compared to the Supreme Court, see Adrian Vermeule, Our Schmittian Administrative Law, Harv. L. Rev. (forthcoming 2009).
} 
attacks, we might expect courts to adopt a general rule of deference, perhaps on the theory that any "balancing" should be tipped in the government's favor. The salience of the attacks would seem likely to produce such deference. But as the attacks receded in time, and as no fresh attack occurred, a somewhat more aggressive posture might be expected. Alongside the passage of time, signals from the Supreme Court seemed inconsistent with complete deference. ${ }^{43}$ For this reason as well, a higher rate of invalidation should be expected in the more recent period.

The absence of any discernible change over time is a genuine puzzle. We can imagine four explanations. First, the hypothesis about salience effects might simply be wrong. It might simply be the case that the judicial posture in 2002 was not different from the judicial posture in 2007. Second, selection effects might be responsible for the absence of changes over time. In the immediate aftermath of the attacks, litigants might have been reluctant to challenge government action unless it was clearly unlawful; more recently, they might be bringing closer cases.

Third, the invalidation rates might mask important qualitative differences. Perhaps judges have indeed been taking a more aggressive approach, but perhaps their aggressiveness manifests itself, not in a higher invalidation rate, but in a willingness to strike down a few especially important programs, which they might have validated a few years before. Fourth, the absence of a discernible change might reflect the growing number of Republican (Bush) appointees to the federal courts, which might produce a shift in favor of the government in national security cases. Because the composition of the courts is not constant over time, a general decrease in salience effects, and hence greater judicial willingness to scrutinize government action, might be counteracted by new appointments to the federal bench.

Unfortunately, the data do not permit us to choose among these four accounts. But a close reading of the cases does suggest that there are not fundamental differences in the posture of courts across the various periods; any such differences, if they even exist, are far more subtle than might be anticipated.

4. A future inquiry (about the past). The study here is limited to national security cases after 9/11. It would be most valuable to ask the following question: What is the invalidation rate, in such cases, before 9/11? Suppose that in the relevant period, the invalidation rate is 40 percent. If so, we might be confident that there has been a "9/11 effect," in the sense that courts are now far more deferential than they were.

A study of this sort would be quite valuable, and it would cast some light on the findings here. But it would raise its own puzzles. First, the number of national security cases, in the decades before $9 / 11$, is relatively small; it would not be simple to obtain a sufficient large sample to produce helpful comparisons. Second, the national security cases before $9 / 11$ are hardly the same as the national security cases after 9/11. To put the point provocatively, a comparison between the two might be a bit like comparing

${ }^{43}$ The most prominent of these is Hamdi v Rumsfeld, 542 U.S. 407 (2004). 
punitive damages cases with national security cases. The reason is that the issues in the pre-9/11 era were so fundamentally different from those in the post-9/11 era that to treat them all as part of a unitary category called "national security cases" is probably unhelpful. Third, selection effects would confound comparisons. Litigants may well have different inclinations after 9/11, and hence it would not be easy to offer confident comparisons of invalidation rates in the different periods.

\section{B. Ideological Voting}

1. No compression. A reasonable prediction would be that in the aftermath of the attacks of 9/11, Democratic and Republican appointees would not be fundamentally different from one another. The hypothesis would be that the tragic consequences of the attacks, especially in the first decade after they occurred, would greatly compress ideological differences. There are at least crude analogies in the past. The Court's decision in Brown v. Bd. of Education, for example, led to an apparent consensus between Republican and Democratic appointees, for a long period, in segregation cases; between 1945 and 1965, the two sets of appointees agreed with one another. ${ }^{44}$

Notably, no such compression is observed. Strikingly, the different inclinations of the two sets of appointees are strong enough to break out even in the aftermath of a national catastrophe. As we have seen, the 11 percent difference is not massive. But as we have also seen, it is statistically significant, and it is within the general range of differences observed in other areas of the law.

2. A future inquiry (about the future) - a party effect?. In all of the relevant cases, federal judges confronted a Republican administration. Is this relevant? Would different judicial voting patterns be found if the pertinent measures had been undertaken by a Democratic administration? A plausible hypothesis would be that judges display an independent party effect -- in the sense that Republican appointees are more skeptical of Democratic administrations than of Republican administrations, while Democratic appointees show the opposite pattern.

In important domains of administrative law, a party effect is indeed demonstrated. In reviewing interpretations of law by the Environmental Protection Agency and the National Labor Relations Board, federal judges are especially willing to uphold decision headed by a president of the same political party as the president who appointed them. ${ }^{45}$ Consider the following table ${ }^{46}$ :

\footnotetext{
${ }^{44}$ See Sunstein et al., supra note, at 41.

${ }^{45}$ See Miles and Sunstein, Do Federal Judges Makes Regulatory Policy, supra note, at 850.

${ }^{46}$ Id.
} 
Table 1

Validation Rates of Court of Appeals Judges

by Party of Appointing and Current President in Chevron Cases

(Means, Standard Errors in Parentheses, and Number of Observations in Brackets)

\begin{tabular}{|c|c|c|c|c|}
\hline \multirow[b]{2}{*}{ Party of Appointing President } & \multirow[b]{2}{*}{$\begin{array}{c}\text { Total } \\
(1)\end{array}$} & \multicolumn{3}{|c|}{ Party of Current President } \\
\hline & & $\begin{array}{c}\text { Democratic } \\
(2)\end{array}$ & $\begin{array}{c}\text { Republican } \\
\text { (3) }\end{array}$ & $\begin{array}{l}\text { Difference of } \\
(2)-(3):\end{array}$ \\
\hline (A) Democrat & $\begin{array}{l}.640 \\
(.027) \\
{[311]}\end{array}$ & $\begin{array}{c}.698 \\
(.043) \\
{[116]}\end{array}$ & $\begin{array}{c}.605 \\
(.035) \\
{[195]}\end{array}$ & $\begin{array}{l}.093^{*} \\
(.056)\end{array}$ \\
\hline (B) Republican & $\begin{array}{c}.637 \\
(.025) \\
{[369]}\end{array}$ & $\begin{array}{c}.592 \\
(.038) \\
{[169]}\end{array}$ & $\begin{array}{c}.675 \\
(.033) \\
{[200]}\end{array}$ & $\begin{array}{c}-.083 * \\
\mathbf{( . 0 5 0 )}\end{array}$ \\
\hline Difference of (A) - (B): & $\begin{array}{c}.003 \\
(.037)\end{array}$ & $\begin{array}{l}.107 * \\
(.058)\end{array}$ & $\begin{array}{r}-.070 \\
(.048)\end{array}$ & - \\
\hline
\end{tabular}

Note: * denotes difference significant at $10 \%$ level, and ** denotes difference significant at $5 \%$ level.

Differences may not match exactly due to rounding.

It would not be surprising if a similar effect were observed in the domain of national security. Perhaps Republican appointees would be less deferential to government intrusions on the domain of liberty, if those intrusions were undertaken by a Democratic administration. Perhaps Democratic appointees would be more deferential to government if a Democratic president headed the executive branch. It would be most valuable to see whether ideological compression would be observed under those circumstances. ${ }^{47}$

\section{Panel Effects}

To understand the absence of discernible panel effects, we need to know something about ideological dampening and ideological amplification.

1. Dampening. What causes ideological dampening? There are several answers. In some cases, the isolated judge is undoubtedly convinced by his colleagues notwithstanding a possible disposition to rule the other way. Sitting with two Republican appointees in an affirmative action case, the Democratic appointee might be persuaded that under existing law, the program is indefensible. In other cases, ideological dampening is likely a product of internal dynamics in which the isolated judge accepts the result in return for some concessions in the analysis. Sitting with two Democratic appointees in a campaign finance case, the Republican appointee might vote to uphold the program so long as the opinion is narrow and does not venture far beyond the particular facts. To this extent, ideological dampening, measured only in terms of votes,

\footnotetext{
${ }^{47}$ For striking evidence of a significant party effect among citizens, see Geoffrey Cohen, Party Over Policy: The Dominating Impact of Group Influence On Political Beliefs, 85 J Personality and Social Psych 808 (2003).
} 
probably understates the role of the isolated judge. Even if Rs look like Ds when they sit on majority D panels, and even if Ds look like Rs when they sit on majority R panels, they might have succeeded in moving the opinion in their preferred directions.

In still other cases, the isolated judge may privately disagree with the result, but may conclude that it is not worthwhile to dissent. By hypothesis, a dissenting opinion will not change the outcome, and its production will take some work and may ruffle some feathers. It is true that on some occasions, a dissenting opinion might increase the likelihood of en banc or Supreme Court review, but both of these are relatively rare. For this reason, a judge might conclude that it is better to join the majority, on the ground that something is gained and nothing is lost. A form of internal cost-benefit balancing may argue in favor of the collegial concurrence even if the judge does not, in fact, agree with the majority's conclusion.

Finally, many judges appear to follow an informal rule of reciprocity, in accordance with which they will not always or even ordinarily dissent from opinions with which they do not agree, in the understanding that other judges will follow the same rule. The basic norm might well be to accept the majority's conclusion, at least if the stakes are not terribly high, with the understanding that this norm is generally held. A rule of reciprocity would seem to fit well with the internal calculation in the usual run of cases: A dissenting opinion imposes burdens and by hypothesis is likely to produce no change, and hence it may makes sense for judges not to dissent despite their private disagreements.

We might see ideological dampening as a reflection of the more general power of conformity pressures. ${ }^{48}$ When people find themselves isolated with a different view from that of unanimous others, they often tend to yield. ${ }^{49}$ They do so either because those views carry information about what is true, or because they do not want to appear wrong or confused to others. ${ }^{50}$ The dynamic among federal judges is not at all the same, but it is overlapping. The evidence suggests that judges are apparently influenced by the views of their colleagues and they might well be attempting to avoid the disapproval, and occasional unpleasantness, that can be produced by a dissenting opinion. Note in this regard that ideological dampening can be found on every federal court of appeals - with the single exception of the United States Court of Appeals for the Sixth Circuit. ${ }^{51}$ According to informal lore, Republican and Democratic appointees do not get along well on that circuit, ${ }^{52}$ and the absence of a norm of reciprocity may be partly cause and partly effect of that fact.

\footnotetext{
${ }^{48}$ See Solomon Asch, Opinions and Social Pressure, in Readings About the Social Animal 13 (Elliott Aronson ed.) (1995).

${ }^{49}$ Id.

${ }^{50}$ Id.

${ }^{51}$ Sunstein et al., supra note, at 113.

${ }^{52}$ See, for example, the remarks of Judge Gilbert Merritt in http://www.enquirer.com/editions/2003/09/03/loc_ohcourtplayers03.html
} 
2. Amplification. At first glance, ideological amplification seems more mysterious. Two Democratic appointees, on a three-judge panel with one Republican appointee, should be able to obtain the result they prefer. Why do they show significantly more moderate patterns on mixed panels than on unified ones?

One explanation points to group polarization. It is well-known that like-minded people typically end up in a more extreme position in line with their predeliberation tendencies. ${ }^{53}$ Perhaps RRR and DDD panels participate in a process of group polarization, in which judges move one another to more extreme voting patterns. The standard explanation of group polarization supports this account. On that account, such polarization is produced by the exchange of information within the relevant group. ${ }^{54}$ If, for example, a group of people is discussing climate change, and is antecedently inclined to believe that it poses serious risks, the pool of arguments favors that antecedent belief. As those arguments are revealed, people tend to shift. It is easy to imagine a similar process within a judicial panel, as different arguments, in (say) a case involving disability discrimination, move people toward more extreme points on unified panels.

An alternative explanation points not toward the relatively extreme behavior of judges on unified panels, but to the more moderate behavior of judges who constitute a majority on mixed panels. On this view, that more moderate behavior is what must be explained. The simplest account would stress a whistleblower effect. ${ }^{55}$ The presence of a Republican appointee imposes a discipline on two Democratic appointees, just as the presence of a Democratic appointees imposes a discipline on two Republican appointees. Perhaps legally doubtful results are more possible on unified panels than on mixed ones, because of the absence of a whistleblower on the former. If this is so, that absence helps to explain the relatively extreme behavior of like-minded judges on unified panels. A softened version of the whistleblower argument would point not to results that are legally doubtful in any strong sense, but to the fact that the presence of a minority member may raise arguments and impose discipline on the majority, producing more moderate voting patterns.

Note that whatever the explanation for ideological amplification, its actual effects are likely to be larger than what can be picked up by a quantitative examination of judicial voting patterns. Opinions matter, not merely votes, and if amplification is occurring, DDD and RRR panels are likely to show relatively extreme opinions. The empirical finding of ideological dampening is probably overstated in an important respect, because it does not speak to opinions, on which the isolated judge likely has an effect. By contrast, the empirical finding of amplification is probably understated,

\footnotetext{
${ }^{53}$ See Roger Brown, Social Psychology: The Second Edition (1985); Cass R. Sunstein, Going to Extremes (forthcoming 2009).

${ }^{54}$ See Brown, supra note.

55 See Frank Cross and Emerson Tiller, Judicial Partisanship and Obedience to Legal Doctrine: Whistleblowing on the Federal Courts of Appeals, 107 Yale LJ 2155 (1998).
} 
because there is every reason to think that opinions are unusually extreme on unified panels.

3. No dampening, no amplification. How, then, can the apparent absence of panel effects be explained in national security cases post-9/11? The best answer is that judicial judgments are firm - so much so that the views of panel members do not matter. In the domain of national security, differences between Republican and Democratic appointees appear to be so strongly held that the views of panel members simply do not matter.

Ideological dampening does not occur for that reason. Compare the only other domains, to date, in which dampening has been found not to occur: capital punishment and abortion. ${ }^{56}$ In those domains, the absence of dampening is not entirely surprising. If antecedent convictions are deeply held, none of the mechanisms that account for dampening will be strong enough to move judicial votes. In such areas, judges will not be convinced by their colleagues. They will be willing to do the work that is necessary to produce a dissent, perhaps in the hope of attracting Supreme Court attention or influencing future courts. They will be willing to create the kinds of disruption that might attend dissenting opinions. Where the stakes are high, the informal norm of reciprocity, reducing dissenting opinions, is qualified or breaks down. A key finding here the area of national security falls in the same category as abortion and capital punishment.

I have suggested that amplification occurs either because of group polarization or because of an absence of a whistleblower effect. But if judges already have quite strong convictions, then they are not likely to be polarized by internal discussions. And if judges do not trust those who purport to be whistleblowers, then they are not likely to be moved by them. These points help to explain why amplification is not observed here.

\section{Conclusion}

Some people believe that when national security is threatened, federal judges should adopt a strong presumption in favor of government action. Other people believe that when national security is threatened, federal judges need to maintain a strong hand in order to prevent official overreaching. The evidence suggests that in the aftermath of the attacks of 9/11, the courts of appeals have rejected both of these polar positions. They show unusually high deference rates without providing anything like a blank check to the executive. Notably and somewhat surprisingly, the rate of invalidation has not increased over time, as vivid memories of the attacks recede.

At the same time, the significant split between Republican and Democratic appointees demonstrates that ideological differences are playing a large role in this domain. Indeed, the magnitude of the difference between the two sets of appointees is

\footnotetext{
${ }^{56}$ Sunstein et al., supra note, at 55. Panel effects cannot be demonstrated in the area of gay and lesbian rights, but because the sample size is so small, the lack of a demonstrated effects is not worth much. The shape of the figure suggests that both dampening and polarization might be occurring. See id.
} 
similar to that in numerous other areas of law. Contrary to a plausible hypothesis, ideological compression is not observed.

Perhaps the most striking finding involves the absence of panel effects. While the sample size is relatively small, the evidence suggests that judicial views are firmly entrenched, and hence judicial votes appear unaffected by the views of judicial colleagues. This is an unusual and noteworthy pattern. Ideological dampening and ideological amplification are pervasive on the federal courts of appeals, but they cannot be found in national security cases post-9/11.

Readers with comments should address them to:

Professor Cass R. Sunstein

University of Chicago Law School

1111 East 60th Street

Chicago, IL 60637

csunstei@law.harvard.edu 


\section{Chicago Working Papers in Law and Economics (Second Series)}

For a listing of papers 1-399 please go to Working Papers at http://www.law.uchicago.edu/Lawecon/index.html

400. Shyam Balganesh, Foreseeability and Copyright Incentives (April 2008)

401. Cass R. Sunstein and Reid Hastie, Four Failures of Deliberating Groups (April 2008)

402. M. Todd Henderson, Justin Wolfers and Eric Zitzewitz, Predicting Crime (April 2008)

403. Richard A. Epstein, Bell Atlantic v. Twombly: How Motions to Dismiss Become (Disguised) Summary Judgments (April 2008)

404. William M. Landes and Richard A. Posner, Rational Judicial Behavior: A Statistical Study (April 2008)

405. Stephen J. Choi, Mitu Gulati, and Eric A. Posner, Which States Have the Best (and Worst) High Courts? (May 2008)

406. Richard H. McAdams and Janice Nadler, Coordinating in the Shadow of the Law: Two Contextualized Tests of the Focal Point Theory of Legal Compliance (May 2008, revised October 2008)

407. Cass R. Sunstein, Two Conceptions of Irreversible Environmental Harm (Mary 2008)

408. Richard A. Epstein, Public Use in a Post-Kelo World (June 2008)

409. Jonathan R. Nash, The Uneasy Case for Transjurisdictional Adjudication (June 2008)

410. Adam B. Cox and Thomas J. Miles, Documenting Discrimination? (June 2008)

411. M. Todd Henderson, Alan D. Jagolinzer, and Karl A. Muller, III, Scienter Disclosure (June 2008)

412. Jonathan R. Nash, Taxes and the Success of Non-Tax Market-Based Environmental Regulatory Regimes (July 2008)

413. Thomas J. Miles and Cass R. Sunstein, Depoliticizing Administrative Law (June 2008)

414. Randal C. Picker, Competition and Privacy in Web 2.0 and the Cloud (June 2008)

415. Omri Ben-Shahar, The Myth of the “Opportunity to Read” in Contract Law (July 2008)

416. Omri Ben-Shahar, A Bargaining Power Theory of Gap-Filling (July 2008)

417. Omri Ben-Shahar, How to Repair Unconscionable Contracts (July 2008)

418. Richard A. Epstein and David A. Hyman, Controlling the Costs of Medical Care: A Dose of Deregulation (July 2008)

419. Eric A. Posner, Erga Omnes Norms, Institutionalization, and Constitutionalism in International Law (August 2008)

420. Thomas J. Miles and Eric A. Posner, Which States Enter into Treaties, and Why? (August 2008)

421. Cass R. Sunstein, Trimming (August 2008)

422. Cass R. Sunstein, Second Amendment Minimalism: Heller as Griswold (August 2008)

423. Richard A. Epstein, The Disintegration of Intellectual Property (August 2008)

424. John Bronsteen, Christopher Buccafusco, and Jonathan Masur, Happiness and Punishment (August 2008)

425. Adam B. Cox and Thomas J. Miles, Judicial Ideology and the Transformation of Voting Rights Jurisprudence (August 2008)

426. Daniel Abebe and Jonathan S. Masur, A Nation Divided: Eastern China, Western China, and the Problems of Global Warming (August 2008)

427. William Birdthistle and M. Todd Henderson, One Hat Too Many? Investment Desegregation in Private Equity (August 2008)

428. Irina D. Manta, Privatizing Trademarks (abstract only) (September 2008)

429. Paul J. Heald, Testing the Over- and Under-Exploitation Hypothesis: Bestselling Musical Compositions (1913-32) and Their Use in Cinema (1968-2007) (September 2008)

430. M. Todd Henderson and Richard A. Epstein, Introduction to “The Going Private Phenomenon: Causes and Implications” (September 2008)

431. Paul Heald, Optimal Remedies for Patent Infringement: A Transactional Model (September 2008)

432. $\quad$ Cass R. Sunstein, Beyond Judicial Minimalism (September 2008)

433. Bernard E. Harcourt, Neoliberal Penality: The Birth of Natural Order, the Illusion of Free Markets (September 2008) 
434. Bernard E. Harcourt, Abolition in the U.S.A. by 2050: On Political Capital and Ordinary Acts of Resistance (September 2008)

435. Robert Cooter and Ariel Porat, Liability for Lapses: First or Second Order Negligence? (October 2008)

436. Ariel Porat, A Comparative Fault in Defense Contract Law (October 2008)

437. Richard H. McAdams, Beyond the Prisoners' Dilemma: Coordination, Game Theory and the Law (October 2008)

438. Dhammika Dharamapala, Nuno Garoupa, and Richard H. McAdams, Belief in a Just World, Blaming the Victim, and Hate Crime Satatutes (October 2008)

439. M. Todd Henderson, The Impotence of Delaware's Taxes: A Short Response to Professor Barzuza's Delaware's Compensation (October 2008)

440. Richard McAdams and Thomas Ulen, Behavioral Criminal Law and Economics (November 2008)

441. Cass R. Sunstein, Judging National Security post-9/11: An Empirical Investigation (November 2008) 